\title{
Geothermal source heat pump performance for a greenhouse heating system: an experimental study
}

\author{
Alexandros Sotirios Anifantis, Simone Pascuzzi, Giacomo Scarascia-Mugnozza \\ Department of Agricultural and Environmental Science, University of Bari Aldo Moro, Bari, Italy
}

\begin{abstract}
Greenhouses play a significant function in the modern agriculture economy even if require great amount of energy for heating systems. An interesting solution to alleviate the energy costs and environmental problems may be represented by the use of geothermal energy. The aim of this paper, based on measured experimental data, such as the inside greenhouse temperature and the heat pump performance (input and output temperatures of the working fluid, electric consumption), was the evaluation of the suitability of low enthalpy geothermal heat sources for agricultural needs such as greenhouses heating. The study was carried out at the experimental farm of the University of Bari, where a greenhouse was arranged with a heating system connected to a ground-source heat pump (GSHP), which had to cover the thermal energy request. The experimental results of this survey highlight the capability of the geothermal heat source to ensue thermal conditions suitable for cultivation in greenhouses even if the compressor inside the heat pump have operated continuously in a fluctuating state without ever reaching the steady condition. Probably, to increase the performance of the heat pump and then its coefficient of performance within GSHP systems for heating greenhouses, it is important to analyse and maximise the power conductivity of the greenhouse heating system, before to design an expensive borehole ground exchanger. Nevertheless, according to the experimental data obtained, the GSHP systems are effective, efficient and environmental friendly and may be useful to supply the heating energy demand of greenhouses.
\end{abstract}

Correspondence: Simone Pascuzzi, Department of Agricultural and Environmental Science, University of Bari Aldo Moro, via Amendola 165/A, 70126, Bari, Italy.

Tel./Fax: +39.080.544.22.14. E-mail: simone.pascuzzi@uniba.it

Key words: Geothermal heat pump; borehole-probe conductivity; greenhouse heating.

Conflict of interest: the authors declare no potential conflict of interest.

Received for publication: 4 February 2016.

Accepted for publication: 11 July 2016.

(C) Copyright A.S. Anifantis et al., 2016

Licensee PAGEPress, Italy

Journal of Agricultural Engineering 2016; XLVII:544

doi:10.4081/jae.2016.544

This article is distributed under the terms of the Creative Commons Attribution Noncommercial License (by-nc 4.0) which permits any noncommercial use, distribution, and reproduction in any medium, provided the original author(s) and source are credited.

\section{Introduction}

Greenhouses play a significant function in the modern agriculture allowing off-season cultivation of crops and flowers and growth of varieties of flora also in areas where the natural climate is not conducive (Baldoin et al., 2008; Giacomelli et al., 2012). Nowadays oil, natural gas and electric energy are generally used to supply the great majority of the greenhouses (Vox et al., 2008), contributing to the fossil energy resources depletion, to greenhouse gas emissions and to environmental impact of greenhouse industry. An interesting solution to alleviate the energy and environmental problems connected to the current fossil-based energy systems for greenhouses climate control may be represented by the use of geothermal energy. The geothermal heating systems have a low environmental impact on the agricultural sector applications and are economically advantageous especially for greenhouse heating demands (Adaro et al., 1999; Kondili and Kaldellis, 2006; Chai et al., 2012; Benli, 2013). Generally electricity powers the heat pump and its energy efficiency is expressed by the coefficient of performance (COP), which is the ratio between the thermal energy produced and the electricity consumed by the heat pump (Friso, 2014). Low operating costs, reliable operation and low need for maintenance are the main advantages of geothermal heat pumps (Barbier, 2002; Colangelo et al., 2012) that do not produce direct emissions of greenhouse gases (Lund et al., 2005). A further reduced emission of greenhouse gases may be obtained powering heat pumps through electricity generated by renewable energy sources like solar or wind (Deshmukh and Boehm, 2008; Ozgener, 2010; Blanco et al., 2013). Actually some studies have investigated also on the integration of solar hydrogen power systems with geothermal heating systems with the aim to provide a possible option for powering stand-alone greenhouses (Ganguly et al., 2010; Blanco et al., 2014; Pascuzzi et al., 2016a, 2016b). A heat exchange system with the subsoil linked to a heat pump thermal generator, in turn connected to a heating distribution system inside the greenhouse, make up the main components of a greenhouse climate control system fitted with a geothermal heat pump. Using groundsource heat pump (GSHP) systems, the heat exchange with the subsoil takes place by means of a fluid (water or water and propylene glycol) that flows inside the geothermal probes (Cui et al., 2011). Geothermal vertical closed probes generate only thermal exchange without mass flow and then are versatile and environmentally friendly (Benli, 2013), even if these underground heat exchanges are strictly influenced by physical and structural characteristics of the ground, such as thermal conductivity, geothermal gradient, and water content (Florides et al., 2011). Greenhouses' heating does not need very high temperatures of the heat transfer fluid and then the employment of geothermal heat pumps can find a useful application (Dickson and Fanelli, 2004; Russo et al., 2014). Actually experimental studies and commercial applications aimed to evaluate the potential of geothermal heat pumps for greenhouse cultivation have been carried out and the main results in connection with energy consumption, environmental burdens, economic and agronomic aspects have been stimulating (Benli and 
Durmus, 2009; 0'Sullivan et al., 2010). Furthermore the likelihood of employment of geothermal heat pumps for agricultural products drying process, such as the use of heat exchange with the subsurface through open or closed circuits, both vertical and horizontal, have been investigated (Sethi and Sharma, 2008; Fujii and Ohyama, 2009). The aim of this paper, based on measured experimental data, such as the inside greenhouse temperature and the heat pump performance (input and output temperatures of the working fluid, electric consumption), was the evaluation of a specific model of heat pump unit and its employment in connection with a borehole heat exchange. The study was carried out at the experimental farm of the Department of Agricultural and Environmental Science, University of Bari Aldo Moro, located in Valenzano (latitude $41^{\circ}, 1$ ', 12", longitude 16 ${ }^{\circ}, 54$ ', 16"), Bari, Southern Italy, where a greenhouse was arranged with a heating system connected to a GSHP, which had to cover the thermal energy request.

\section{Materials and methods}

\section{Experimental greenhouse - heating system - geother- mal source heat pump}

The experimental greenhouse, fitted with arched shape and realised with a structure formed by tubular galvanised steel, has area $\mathrm{A}_{\mathrm{s}}=48 \mathrm{~m}^{2}$ and volume $V=144 \mathrm{~m}^{3}$. The covering is made of a plastic film of ethylene vinyl acetate having thickness $S_{\mathrm{cf}}=2 \times 10^{-4} \mathrm{~m}$. The total covering film surface is $A_{c f}=115 \mathrm{~m}^{2}$. The heating system is composed by black plastic pipes (length $\mathrm{l}_{\mathrm{hh}}=100 \mathrm{~m}$, diameter $\mathrm{D}_{\mathrm{hh}}=25 \mathrm{~mm}$ ), laid and refolded on the ground, for hot water circulation, in turn linked to a heat pump equipped by a $120 \mathrm{~m}$ vertical double U-bend ground heat exchangers (thermal probe).

\section{Geothermal source heat pump}

The heating pumping unit [Model RAA-EF; Riello spa, Legnago (VR), Italy], according to the technical data provided by the manufacturer, produces an output of $7.0 \mathrm{~kW}$ thermal, absorbing $1.5 \mathrm{~kW}$ of electricity, with energy COP equal to 4.7. It uses R410A as refrigerant fluid circulating inside its circuit and the water mass flows in the both sides (hot and cold) is just the same $\mathrm{M}_{\mathrm{h}}=\mathrm{M}_{\mathrm{c}}=0.28 \mathrm{~kg} \mathrm{~s}^{-1}$. The compound R410A, formed by the mixture of $\mathrm{R} 32$ and $\mathrm{R} 125$ refrigerant fluids (50\% $\mathrm{CH}_{2} \mathrm{~F}_{2} / 50 \% \mathrm{CHF}_{2} \mathrm{CF}_{3}$ ), is almost azeotropic and then at boiling the vapor has the same proportions of constituents as the unboiled mixture; furthermore, its GWP100 $=1900$, that is during 100 years $1 \mathrm{~kg}$ of R410A produces the same damages of $1900 \mathrm{~kg}$ of carbon dioxide (Saner et al., 2010). The heating pumping unit is fitted with a scroll compressor that works trapping and compressing pockets of fluid between a fixed scroll, while the other one orbits eccentrically without rotating. The scroll compressors have several advantages such as an excellent full-load and part-load efficiency and a continuous compression process with almost no pulsation or vibration and are suitable to be controlled by an inverter. As known, an inverter-based variable-speed drive is an interface between the utility input and the compressor motor that controls the speed of the motor by changing the magnitude of voltage, current or frequency. But currently heat pumps manufacturers do not insure the performance of the scroll compressor - inverter combination and assemble only the on/off controls with the scroll compressors (Del Mastro and Noce, 2011).

The on/off control system is driven by a thermostat placed inside the greenhouse that maintains the temperature near the set point of $18^{\circ} \mathrm{C}$. The control system automatically cuts off the electric feed when the air temperature reaches this value; in this operative condition, the heat pump hot side outlet water temperature attains the highest value $\left(\mathrm{T}_{\mathrm{h} 1}=48^{\circ} \mathrm{C}\right)$. Conversely, the control system reactivates the electric feed when the air temperature falls below the set point and $\mathrm{T}_{\mathrm{h} 1}$ is the lowest $\left(\mathrm{T}_{\mathrm{h} 1}=24^{\circ} \mathrm{C}\right)$ in this functional condition. The efficiency of the heat pump unit is strictly influenced by both the hot side outlet $\left(\mathrm{T}_{\mathrm{hl}}\right)$ and inlet $\left(\mathrm{T}_{\mathrm{h} 2}\right)$ water temperatures, in turn affected by the performance of the heating system placed inside the greenhouse, the cold side outlet $\left(\mathrm{T}_{\mathrm{cl}}\right)$ and inlet $\left(\mathrm{T}_{\mathrm{c} 2}\right)$ water temperatures, in turn conditioned by the performance of the borehole-thermal probe in the ground. The authors sized the thermal probe in the ground in accordance with the German standard (VDI, 2004) on the strength of the specific heat evulsion by ground. The heat exchanger between the probe and the ground was evaluated and designed so that to keep the sustainability energy production without alteration of the thermal characteristics of the subsoil in the long term (Rybach, 2010; SIA, 2010). The borehole for the probe was built in two steps. In the first step a $3 \mathrm{~m}$ vertical $180 \mathrm{~mm}$ nominal diameter hole was drilled and a polyvinyl chloride $160 \mathrm{~mm}$ nominal diameter, $3.2 \mathrm{~mm}$ thickness, pipe was inserted. In the second step a 120 $\mathrm{m}$ vertical $140 \mathrm{~mm}$ nominal diameter hole was drilled (borehole radius $r_{b}=70 \mathrm{~mm}$ ). During the drilling time the ground composition and stratigraphy was investigated to evaluate the thermal characteristic of the subsoil: limestone and large clay layers and crevices compose mainly the ground (Figure 1). Furthermore, an aquifer has been found at about $96 \mathrm{~m}$ of depth where there were layers of fissured claystone and fissured limestone (Figure 1). The thermal conductivities corresponding to the soil composition have been evaluated according to the German standard (VDI, 2009) (Figure 1).

The thermal probe, formed by a double $32 \mathrm{~mm}$ nominal diameter (effective probe-pipe internal radius $\mathrm{r}_{\text {eff }}=16 \mathrm{~mm}$ and $2.9 \mathrm{~mm}$ thickness) U-bend pipe (number of pipes inside the borehole $n=4$ ) composed by high resistance cross-linked polyethylene (PEX) with a thermal range of $-40^{\circ} \mathrm{C} \div+95^{\circ} \mathrm{C}$, was located inside the realised drilling. The double U-bend disposition has the following characteristics: continuity of operations in case of one pipe occlusion; lower thermal resistance than single $\mathrm{U}$ bend type; lower nominal diameter of pipe and consequent high speed of fluid inside; high boundary area extend; high possibility of thermal short circuit (Llopis and Rodrigo, 2008).

The borehole grouting was placed through injection on pressure of concrete from the bottom by means of a polyethylene pipe placed

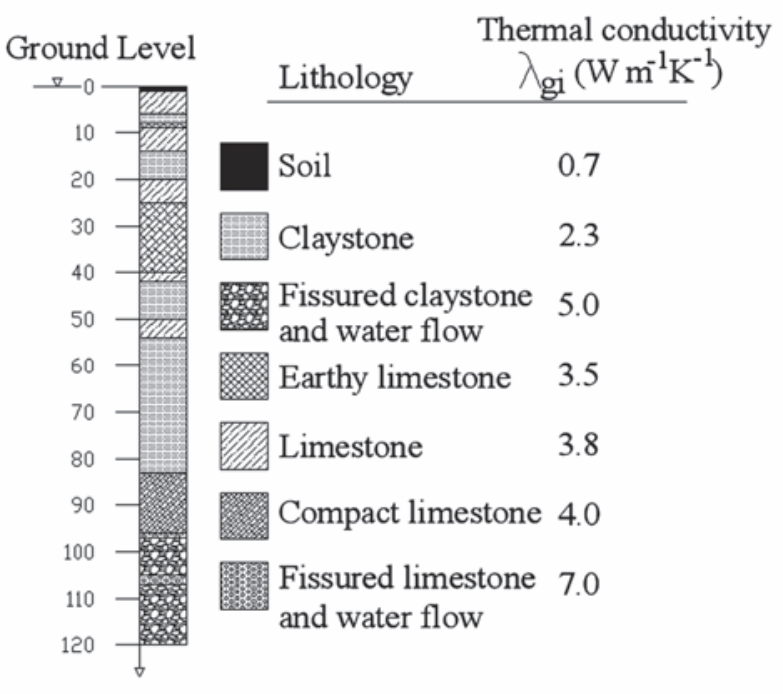

Figure 1. Litho-stratigraphy performed during the drilling. 
between the PEX pipes. The undisturbed ground temperature is $\mathrm{T}_{\mathrm{g}}=18^{\circ} \mathrm{C}$ at undisturbed ground temperature radius $r_{g}=0.5 \mathrm{~m}$. The heat transfer circulating fluid was water because the altitude of the site $\left(130 \mathrm{~m}_{\mathrm{ass}}\right)$ and its climatic conditions did not produce fluid freezing risks. Moreover, the use of water without antifreeze fluids (propylene glycol, ethylene glycol, and so on) allows preventing any pollution of the surrounding environment or chemical incompatibility with the materials of the system in case of probe crashed (Ozgener, 2010). Within the period November 2014 - March 2015 experimental measures concerning the greenhouse inside and outside air temperatures as well as with reference to the heat pump $\mathrm{T}_{\mathrm{hl}}, \mathrm{T}_{\mathrm{h} 2}, \mathrm{~T}_{\mathrm{cl}}$ and $\mathrm{T}_{\mathrm{c} 2}$ were carried out. The air temperatures inside and outside the greenhouse were measured by means of ventilated platinum resistance thermometers (Pt100) probes, whose data were collected through a data loggers CR10X (Campbell Scientific, Inc., Logan, UT, USA), set with a sampling time of $10 \mathrm{~s}$ and a data storage time lag of 15 min. Furthermore, Pt100 probes measured the outlet and inlet temperatures of both the sides (hot and cold) of the heat pump. Finally, a digital multimeter measured its electricity consumption.

\section{Theoretical aspects}

\section{Greenhouse thermal systems and energy requirement}

The thermal energy requirement of a greenhouse depends on many factors as the solar radiation, the inside and outside air temperature, the wind speed, the soil temperature, the greenhouse area, the geometry and orientation, the thermal proprieties of covering materials, the air ventilation and loss, and so on. For the aim of this study only the main thermal exchanges has been taken into account, even if the mathematical dynamic model of the greenhouse thermal behavior is very composite (Ozgener and Hepbasli, 2005). Considering the steady state and the overnight winter conditions, the heating power requirement $\mathrm{Q}_{1}[\mathrm{~W}]$ of a hot water pipes heating system has been evaluated as the sum of the thermal convection and radiation exchanged among a long black pipe and the internal greenhouse air, soil, and covering film through the equation:

$Q_{1}=Q_{h, i}+Q_{h, c f}+Q_{h, s}$

where:

$\mathrm{Q}_{\mathrm{h}, \mathrm{i}}$, convection power loss between heating system and inside air [W]; $\mathrm{Q}_{\mathrm{h}, \mathrm{f}}$, radiation power loss between heating system and greenhouse covering plastic film layer [W];

$\mathrm{Q}_{\mathrm{h}, \mathrm{s}}$, thermal radiation power loss between the heating system and the surface of the inside soil [W].

$\mathrm{Q}_{\mathrm{h}, \mathrm{i}}$ and $\mathrm{Q}_{\mathrm{h}, \mathrm{f}}$, in turn, are linked to the thermic power balance, respectively, of the internal air radiation and of the covering plastic film layer (Bianchi and Scarascia-Mugnozza, 1996). Therefore, in steady and overnight winter conditions, the following equations have been considered:

carriage return:

$Q_{\mathrm{h}, \mathrm{i}}=Q_{\mathrm{i}, 0}+Q_{\mathrm{i}, \mathrm{s}}+\mathrm{Q}_{\mathrm{i}, \mathrm{ff}}$

thermic power balance of the covering plastic film layer:

$Q_{\mathrm{h}, \mathrm{f}}+Q_{\mathrm{i}, \mathrm{ff}}=Q_{\mathrm{cf}, 0}+Q_{\mathrm{cf}, \mathrm{cs}}+Q_{\mathrm{cf}, \mathrm{s}}$

where:

$\mathrm{Q}_{\mathrm{i}, 0}$, thermal power loss due to leakage of inside air [W];

$\mathrm{Q}_{\mathrm{i}, \mathrm{s}}$, thermal convective power loss between inside air and soil [W];

$\mathrm{Q}_{\mathrm{i}, \mathrm{c}}$, thermal convection and conduction power loss between inside air and covering film [W];
$\mathrm{Q}_{\mathrm{h}, \mathrm{f}}$, thermal radiation power loss between heating system and covering film [W];

$\mathrm{Q}_{\mathrm{cf}, 0}$, thermal convection power loss between covering film and outside air [W];

$\mathrm{Q}_{\mathrm{cf}, \mathrm{ss}}$, thermal radiation power loss between covering film and overnight sky layer $[\mathrm{W}]$;

$\mathrm{Q}_{\mathrm{cf}, \mathrm{s}}$, thermal radiation power loss between covering plastic film layer and outside soil $[\mathrm{W}]$.

The system of Eqs. (1), (2), (3) allowed determining the heating power requirement $Q_{1}$ for the set up experimental greenhouse. The authors designed the greenhouse heating system according to the average temperature of the winter night-time, out of blue sky, measured in Valenzano in the period $2014-2015$, that is $\mathrm{T}_{0}=8^{\circ} \mathrm{C}$ and considering an average greenhouse indoor temperature of $\mathrm{T}_{\mathrm{i}}=14^{\circ} \mathrm{C}$.

\section{Heat pump - borehole heat exchanger system}

The thermal power $\left(Q_{1}\right)[W]$ is supplied by the hot water circulating inside the pipes of the greenhouse heating system, coming from the heat pump, by the following Eq. (2) (Cengel and Ricciardi, 2013):

$\mathrm{Q}_{1}=\mathrm{M}_{\mathrm{h}} \cdot \mathrm{c}_{\mathrm{p}} \cdot\left(\mathrm{T}_{\mathrm{h} 1}-\mathrm{T}_{\mathrm{h} 2}\right)$

where:

$\mathrm{M}_{\mathrm{h}}$ is the mass flow in the hot side of the heat pump [ $\mathrm{kg} \mathrm{s}^{-1}$ ];

$c_{p}$ is the specific heat of water $\left[\mathrm{J} \mathrm{kg}^{-1} \mathrm{~K}^{-1}\right]$;

$\mathrm{T}_{\mathrm{h} 1}$ and $\mathrm{T}_{\mathrm{h} 2}$ are, respectively, the outlet and inlet hot side temperatures of the heat pump [K]. Neglecting the heat loss along the pipes that connect the hot side of the heat pump to the greenhouse, $\mathrm{T}_{\mathrm{h} 1}$ and $\mathrm{T}_{\mathrm{h} 2}$ match, respectively, the input and output temperatures of the heating system inside the greenhouse.

The energy efficiency of the heat pump, i.e., the COP, is the ratio between $Q_{1}$ and the electric power required (L):

$$
\mathrm{COP}=\frac{\mathrm{Q}_{1}}{\mathrm{~L}}=\frac{\mathrm{Q}_{1}}{\mathrm{Q}_{2}-\mathrm{Q}_{1}}
$$

where $Q_{2}$ is the heat power extracted from the underground. COP is strictly linked to the working condition of both the heat exchange systems: the borehole-probe-ground system and the greenhouse heating system.

In the cold side of the heat pump $Q_{2}$ [W] is the thermal power exchanged with the ground through the borehole-probe heat exchanger. $\mathrm{Q}_{2}$ have to meet simultaneously the following equations:

$\mathrm{Q}_{2}=\mathrm{M}_{\mathrm{h}} \cdot \mathrm{c}_{\mathrm{p}} \cdot\left(\mathrm{T}_{\mathrm{cl}}-\mathrm{T}_{\mathrm{c} 2}\right)$

$\mathrm{Q}_{2}=\frac{\left[\mathrm{T}_{\mathrm{g}}-\frac{\left(\mathrm{T}_{\mathrm{cl}}-\mathrm{T}_{\mathrm{c} 2}\right)}{2}\right]}{\mathrm{R}_{\mathrm{T}}}$

where:

$\mathrm{M}_{\mathrm{c}}$ is mass flow in the cold side of the heat pump [ $\mathrm{kg} \mathrm{s}^{-1}$; $\mathrm{T}_{\mathrm{g}}$ is the undisturbed ground temperature, before heat injection; $\mathrm{T}_{\mathrm{cl}}$ and $\mathrm{T}_{\mathrm{c} 2}$ are, respectively, the outlet and inlet cold side temperatures of the heat pump [K]; $\mathrm{R}_{\mathrm{T}}$ is the effective total thermal resistance of the borehole-probe-ground system [ $\left.\mathrm{K} \mathrm{W}^{-1}\right]$.

$T_{g}[K]$ is known and $R_{T}$ is estimated according to the depth of the borehole and the thermic characteristics of the subsoil layers.

\section{Borehole-probe-ground thermal system}

Several technical aspects affect the performance of the thermal sys- 
tem borehole-probe-ground and therefore the evaluation of $R_{T}$ is very complex. A double U-bend pipe formed the geothermal probe placed in the realised borehole. Usually these multi pipes systems are studied as one concentric pipe with an effective thermal resistance from a mathematical point of view (Figure 2A).

Indeed some Authors have simulated the U-shaped pipes as a single pipe of equivalent internal radius $\mathrm{r}_{\mathrm{f}, \mathrm{eq}}$ by the following equation ( $\mathrm{Gu}$ and O'Neal, 1998; Remund, 1999; Shonder and Beck, 1999; Sharqawya et al., 2009):

$$
r_{f, e q}=\sqrt{n \cdot r_{e f f}}
$$

where $r_{\text {eff }}[\mathrm{m}]$ is the actual probe-pipe internal radius and $n$ is the number of pipes inside the borehole.

The temperatures in the fluid channels vary along the boreholeprobe heat exchanger between the inlet fluid temperature into the probe $T_{c, \text { in }}$ and the outlet fluid temperature from the probe $T_{c, \text { out }}$ and the mean fluid temperature $\mathrm{T}_{\mathrm{c}}$ may be evaluable by the following equation:

$$
\mathrm{T}_{\mathrm{c}}=\frac{\left(\mathrm{T}_{\mathrm{c}, \text { in }}+\mathrm{T}_{\mathrm{c}, \text { out }}\right)}{2}
$$

Neglecting the heat loss along the pipes that connect the cold side of the heat pump to the probe placed in the borehole, it results: $\mathrm{T}_{\mathrm{cl}}=\mathrm{T}_{\mathrm{c}, \mathrm{in}}$ and $\mathrm{T}_{\mathrm{c} 2}=\mathrm{T}_{\mathrm{c}, \mathrm{out}}$.

The heat exchanges pertinent to the thermal system borehole-probeground has been approached with reference to a model arranged through thermal resistances connected to each other by end to end or by the same pair of terminals (Figure 2B) (Tinti, 2009). The model points out the following thermal exchanges among: i) the fluid inside the borehole at the average temperature $\mathrm{T}_{\mathrm{c}}$ and the internal pipe surface at temperature $T_{p}$ (thermal resistance of the probe $R_{c}$ ); ii) the internal pipe surface at temperature $\mathrm{T}_{\mathrm{p}}$ and the external pipe surface at temperature $\mathrm{T}_{\mathrm{b}}$ (thermal resistance of the borehole stuffed with bentonite $R_{b}$ ); iii) the external pipe surface at temperature $T_{b}$ and the ground at the undisturbed temperature $\mathrm{T}_{\mathrm{g}}$ (total thermal resistance $\mathrm{R}_{\mathrm{g}}$ obtained considering the thermal resistance $R_{i}$ of each ground layer crossed by the vector fluid inside the probe) (Figure 2B). The effective

A

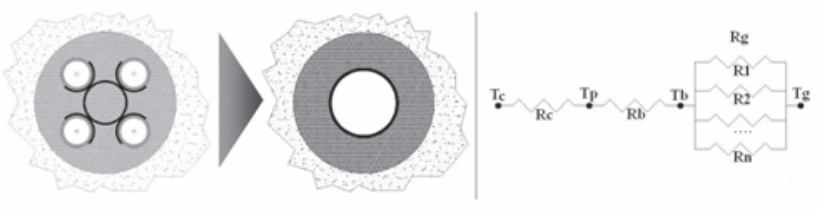

total thermal resistance of the borehole-probe-ground system $R_{T}$ has been calculated by the following (Cengel and Ricciardi, 2013):

$$
R_{T}=R_{c}+R_{b}+R_{g}=\frac{1}{2 \pi}\left(\frac{1}{r_{f, e q} \cdot l_{t} \cdot h_{f, e q}}+\frac{\ln \left(\frac{r_{p, e q}}{r_{f, e q}}\right)}{\lambda_{p} \cdot l_{t}}+\frac{\ln \left(\frac{r_{b}}{r_{p, e q}}\right)}{\lambda_{b} \cdot l_{t}}+\frac{\ln \left(\frac{r_{g}}{r_{b}}\right)}{\sum_{i=1}^{n} \lambda_{g, j} l_{i}}\right)
$$

where:

$\mathrm{l}_{\mathrm{i}}$ active length of the borehole for each soil layer [m];

$\mathrm{l}_{t}$ total active length of the borehole $[\mathrm{m}]$;

$\mathrm{r}_{\mathrm{b}}$ borehole radius $[\mathrm{m}]$;

$\mathrm{r}_{\mathrm{f}, \mathrm{eq}}$ equivalent probe-pipe internal radius [m];

$\mathrm{r}_{\mathrm{g}}$ undisturbed ground temperature radius $[\mathrm{m}]$;

$r_{p, \text { eq }}$ equivalent borehole pipe external radius [m];

$\mathrm{h}_{\mathrm{f}, \mathrm{eq}}$ convection coefficient of the water inside the borehole pipes [ $\mathrm{W} \mathrm{m}^{-2}$

$\mathrm{K}^{-1}$;

$\lambda_{\mathrm{b}}$ borehole filling material thermal conductivity $\left[\mathrm{W} \mathrm{m}^{-1} \mathrm{~K}^{-1}\right]$;

$\lambda_{\mathrm{g}, \mathrm{i}}$ ground thermal conductivity $\left[\mathrm{W} \mathrm{m}^{-1} \mathrm{~K}^{-1}\right.$;

$\lambda_{\mathrm{p}}$ pipe thermal conductivity [ $\mathrm{W} \mathrm{m}^{-1} \mathrm{~K}^{-1}$ ].

According to Eq. (10), the heat extraction rate $\mathrm{q}_{\mathrm{c}}\left[\mathrm{W} \mathrm{m}^{-1}\right]$ at different depth has been calculated with the following:

$$
\mathrm{q}_{\mathrm{c}}=\frac{\left(\mathrm{T}_{\mathrm{g}}-\mathrm{T}_{\mathrm{c}}\right)}{\frac{1}{2 \cdot \pi \cdot \mathrm{r}_{\mathrm{f}, \mathrm{eq}} \cdot \mathrm{h}_{\mathrm{f}, \mathrm{eq}}}+\frac{\ln \left(\frac{\mathrm{r}_{\mathrm{p}, \mathrm{eq}}}{\mathrm{r}_{\mathrm{f}, \mathrm{eq}}}\right)}{2 \cdot \pi \cdot \lambda_{\mathrm{p}}}+\frac{\ln \left(\frac{\mathrm{r}_{\mathrm{b}}}{\mathrm{r}_{\mathrm{p}, \mathrm{eq}}}\right)}{2 \cdot \pi \cdot \lambda_{\mathrm{b}}}+\frac{\ln \left(\frac{\mathrm{r}_{\mathrm{g}}}{\mathrm{r}_{\mathrm{b}}}\right)}{2 \cdot \pi \cdot \lambda_{\mathrm{g}, \mathrm{i}}}}
$$

\section{Results and discussion}

The heat extraction rate $\mathrm{q}_{\mathrm{c}}\left[\mathrm{W} \mathrm{m}^{-1}\right]$ at different depth of the ground, calculated taking into account of the effective litho-stratigraphy performed during the drilling and the corresponding thermal conductivity $\lambda_{\mathrm{g}, \mathrm{i}}$ is reported in Figure 3 . The graph highlights the specific extraction power $\left(\mathrm{q}_{\mathrm{c}}\right)$ concerning the different lithologic layers and in particular the significant increase of this parameter from a depth of about $96 \mathrm{~m}$ where an aquifer was present. At those depths the ground was formed

Figure 2. A) Multi pipes borehole simplified in a single pipe system; B) thermal resistance model of the borehole - probe heat exchanger and ground. $T_{c}$, mean fluid temperature inside the probe; $R_{c}$, thermal resistance of the probe; $T_{p}$, temperature of the internal pipe surface; $R_{b}$ thermal resistance of the borehole stuffed with bentonite; $T_{b}$ temperature of the external pipe surface; $R_{1}, R_{2}, R_{n}$, thermal resistance of the ith layer crossed by the vector fluid inside the probe; $R_{g}$, total thermal resistance of the ground layers; $T_{g}$, undisturbed temperature of the ground.

\section{Extraction thermal specific power $\left(\mathrm{W} \mathrm{m}^{-1}\right)$}

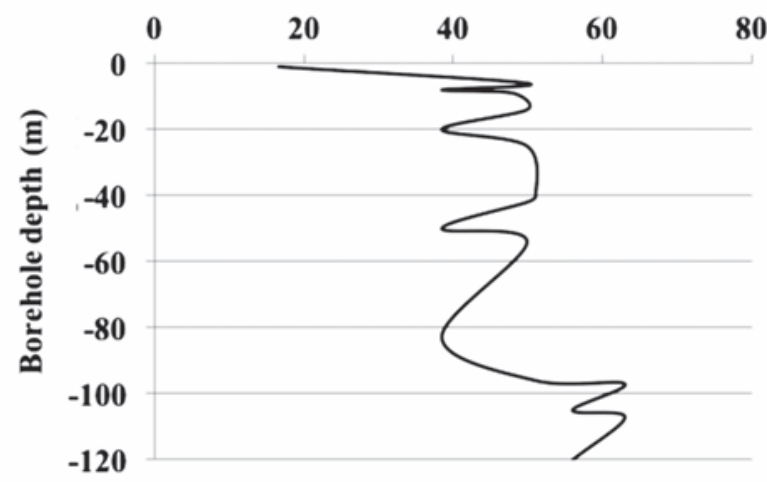

Figure 3. Borehole-probe exchanged thermal specific power. 
by fissured claystone and fissured limestone layers (Figure 1) which were wet and then their thermal conductivities were higher if compared with those ones corresponding to the dry conditions. Therefore, the values of $\lambda_{\mathrm{gi}}$ of the fissured claystone and fissured limestone are more elevated higher than the values pertinent to the other litho-stratigraphy layers (Figure 1). Nevertheless, the evaluated average heat extraction rate has been of $46 \mathrm{~W} \mathrm{~m}^{-1}$ of the probe pipe, value in good agreement with reference to the limits proposed by the German technical standard VDI 4640 (VDI, 2004, 2009). The global heat extraction power can reach therefore $5.5 \mathrm{~kW}$ taking into account the total length of the probe pipe $(120 \mathrm{~m})$.

But during the test period November 2014 - March 2015, the heat extraction rate from the ground had a trend rather irregular and, as example, Figure 4 reports the $Q_{1}$ and the borehole-probe extraction power $\left(Q_{2}\right)$ measured during February 13-15, 2015. $Q_{1}$ and $Q_{2}$ have been calculated through respectively Eqs. (4) and (6) using the outlet and inlet temperatures of both the sides (hot and cold) of the heat pump (Figure 5), whose operating conditions have been analysed through the evaluation of L and the energy COP by Eq. (5) (Figure 6). The trend of the temperatures pertinent to the hot and cold sides of the heat pump ( $T_{h 1}, T_{h 2}, T_{c 1}, T_{c 2}$ ), strictly connected to $Q_{1}$ and $Q_{2}$, points out the involvement of the control system, which automatically interrupted or restored the electric feed when $\mathrm{T}_{\mathrm{h} 1}$ reached respectively higher or lower values than those ones established $\left(48\right.$ and $24^{\circ} \mathrm{C}$ ) (Figure 5).

As a consequence, the operational conditions of the heat pump are the changeable (Figure 6), or rather of the inside compressor, which never reaches the steady-state requirements. Really this working manner of the compressor is affected by the characteristics of the aforesaid control system that works only switching on or off the electric feed in connection with the limit $\mathrm{T}_{\mathrm{hl}}$. A better sophisticated governor system fitted with an electric inverter could allow to control the number of revolutions per minute of the compressor, so decreasing or increasing continuously the flow rate of the refrigerant fluid $\mathrm{R} 410 \mathrm{a}$, circulating inside its circuit, in proportion with $\mathrm{T}_{\mathrm{h} 1}$ and $\mathrm{so}$ avoiding sudden breakdown.

Furthermore, when the compressor restarts after each power cut, the energy efficiency COP has a high value that continually decreases during the running of the machine (Figure 6). Correspondingly, L has an opposite trend with the lowest values at the compressor restarts that increase as the machine operates (Figure 6).

This operating characteristic of the heat pump is due to the heating system inside the greenhouse, which is not able to carry out a suitable thermal exchange, in turn probably caused by both the poor thermal conductivity of the plastic pipes and its characteristic to be refolded on the ground. Doubtless the employment of other materials, such as copper or steel for the pipes ensure an improved thermal exchange even if these materials would be more expensive and thus not consistent for use in greenhouses. The bad thermal exchange of the plastic pipe gives rise to a difference between $\mathrm{T}_{\mathrm{h} 1}$ and $\mathrm{T}_{\mathrm{h} 2}$ less than that designed one, with the raising of $\mathrm{T}_{\mathrm{h} 2}$. Conversely, being constant the rate of the R410A refrigerant fluid circulating inside the compressor also on the cold side of the heating pumping unit, the difference between the temperatures is changed in regard to the designed one with the drop of $\mathrm{T}_{\mathrm{cl}}$. The alteration of $\mathrm{T}_{\mathrm{cl}}$ and $\mathrm{T}_{\mathrm{c} 2}$, in turn induces a variation of the mean fluid temperature $T_{c}$ inside the borehole heat exchanger - Eq. (9) - and then also the heat extraction rate $\mathrm{q}_{\mathrm{c}}$ is affected. In conclusion the trends of $\mathrm{T}_{\mathrm{h} 2}$ and $\mathrm{T}_{\mathrm{c} 1}$ produce a lowering of COP, a scaling up of $\mathrm{L}$ and a progressive decline of the borehole-probe extraction power $\left(\mathrm{Q}_{2}\right)$ (Figure 6).

Figure 7 shows the outdoor-recorded temperatures during some days (February 13-15, 2015) of the test period November 2014 March 2015 and the corresponding ones recorded inside the experimental greenhouse with the realised heating system connected to the GSHP switched on. The graphs highlight a nearly constant difference between the inside and outside air temperature of the geothermal greenhouse when the heating system is working; whereas the low pick temperature of the greenhouse inside air is bigger than $6^{\circ} \mathrm{C}$

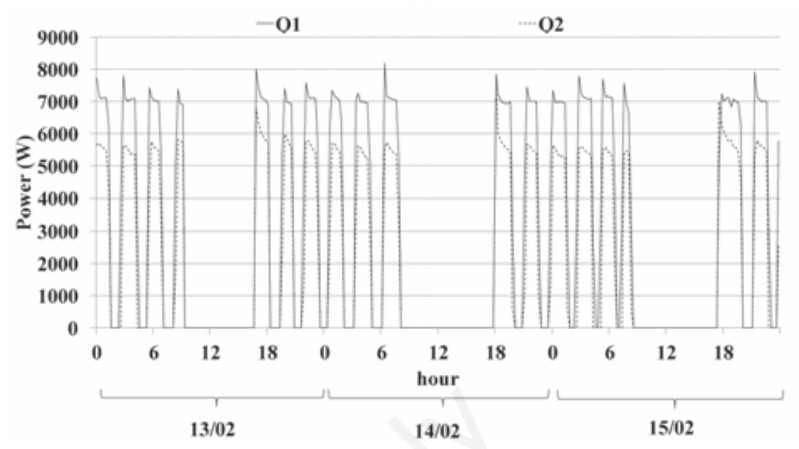

Figure 4. Thermal power produced $\left(Q_{1}\right)$ and the borehole-probe extraction power $\left(Q_{2}\right)$ measured during February 13-15, 2015.



Figure 5. Heat pump hot and cold sides temperatures during February 13-15, 2015.

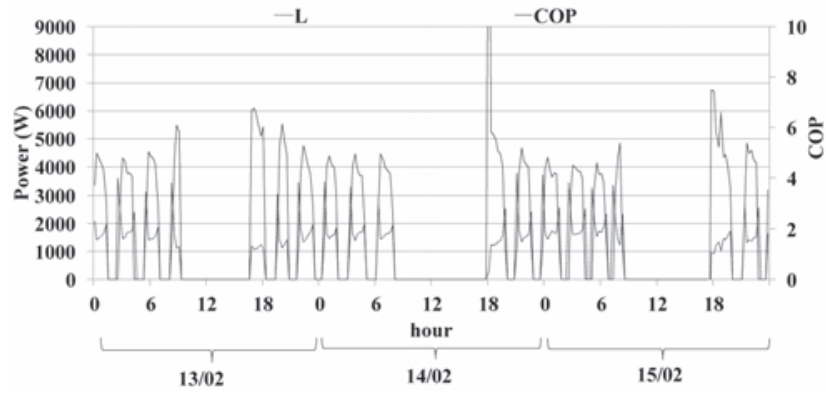

Figure 6. Heat pump operative coefficient of performance (COP) evaluated during February 13-15, 2015. L, the electric power required. 
in order to assure at least the low comfort temperature for the cultivations (Figure 7). Finally, during the test period November 2014 March 2015, the average electric power absorbed by the heat pump has been $1.5 \mathrm{~kW}$ and the average COP 4.7 ; therefore $7 \mathrm{~kW}$ of average thermal power has been produced for heating the greenhouse.

\section{Conclusions}

On a location of Southern Italy, an experimental greenhouse equipped with a heating system connected to a GSHP has been arranged and tested to establish the suitableness of low enthalpy geothermal heat sources for agricultural requirements such as greenhouses heating. The drilling and the positioning of the geothermal probes have been the most burdensome and expensive operations for the achievement of the geothermal source; but also the evaluation of the thermal characteristics of the subsoil have represented a cumbersome aspect of the design of the whole heating system. Data pertinent the working performance of the heat pump and the environmental parameters of the greenhouse have been collected during November 2014 March 2015, when the climate conditions of the location involve the employment of warming. The experimental results of this survey highlight the capability of the geothermal heat source to ensue thermal conditions suitable for cultivation in greenhouses even if the compressor inside the heat pump have operated continuously in a fluctuating state without ever reaching the steady condition. That has been caused by the control system (on/off) of the compressor but also by the heating system inside the greenhouse, composed by black plastic pipes, which did not ensure a suitable thermal exchange. Therefore, the input and output temperatures of the hot water circulating inside the pipes and coming from the heat pump changed continuously giving rise to a feedback on the temperatures of cold side of the heating pumping unit and in turn to the performance of the borehole heat exchanger. Probably, to increase the performance of the heat pump and then its COP within GSHP systems for heating greenhouses, it is important to analyse and maximise the power conductivity of the greenhouse heating system, before to design an expensive borehole ground exchanger. Nevertheless, according to the experimental data obtained, the GSHP systems are effective, efficient and environmental friendly and may be useful to supply the heating energy demand of greenhouses.



Figure 7. Greenhouse inside and outside temperatures during some days of February 2015. $T_{i}$, indoor temperature; $T_{o}$, outdoor temperature.

\section{References}

Adaro J.A., Galimberti P.D., Lema A.I., Fasulo A., Barral J.R. 1999. Geothermal contribution to greenhouse heating. Appl. Energ. 64:241-9.

Baldoin C., Balsari P., Cerruto E., Pascuzzi S., Raffaelli M. 2008. Improvement in pesticide application on greenhouse crops: results of a survey about greenhouse structures in Italy. Acta Hort. 801:609-14.

Barbier E. 2002. Geothermal energy technology and current status: an overview. Renew. Sust. Energy Rev. 6:3-65.

Benli H. 2013. A performance comparison between a horizontal source and a vertical source heat pump systems for a greenhouse heating in the mild climate Elazig, Turkey. Appl. Therm. Eng. 50:197-206.

Benli H., Durmus A. 2009. Evaluation of ground-source heat pump combined latent heat storage system performance in greenhouse heating. Energ. Build. 44:220-8.

Bianchi A., Scarascia-Mugnozza G. 1996. Studio e verifica sperimentale di un modello matematico di simulazione del microclima in serre a regime naturale con copertura in film plastico. Riv. Ing. Agr. 27:220-9.

Blanco I., Anifantis A.S., Pascuzzi S., Scarascia Mugnozza G. 2013. Hydrogen and renewable energy sources integrated system for greenhouse heating. J. Agr. Eng. 44:226-30.

Blanco I., Pascuzzi S., Anifantis A.S., Scarascia Mugnozza G. 2014. Study of a pilot photovoltaic-electrolyzer-fuel cell power system for a geothermal heat pump heated greenhouse and evaluation of the electrolyzer efficiency and operational mode. J. Agr. Eng. 45:111-8.

Cengel Y.A., Ricciardi P. 2013. Termodinamica e trasmissione del calore, $4^{\text {th }}$ ed. Mondadori, Segrate (MI), Italy.

Chai L., Ma C., Ni J.Q. 2012. Performance evaluation of ground source heat pump system for greenhouse heating in norther China. Biosyst. Eng. III:107-17.

Colangelo G., Romano D., De Risi A., Starace G., Laforgia, D. 2012. Un tool in Matlab e Simulink per la simulazione di pompe di calore geotermiche. La Termotecnica 4:63-72.

Cui P., Li X., Man Y., Fang Z. 2011. Heat transfer analysis of pile geothermal heat exchangers with spiral coil. Appl. Energy 88:4113-9.

Delmastro R., Noce G. 2011. Manuale di geotermia a sonde verticali. Hoepli ed., Milano, Italy.

Deshmukh S.S., Boehm R.F. 2008. Review of modelling details related to renewably powered hydrogen systems. Renew. Sust. Energy Rev. 12:2301-30.

Dickson M., Fanelli M. 2004. What is geothermal energy? Istituto di Geoscienze e Georisorse - CNR, Pisa, Italy.

Florides G.A., Pouloupatis P.D., Kalogirou S., Messaritis V., Panayides I., Zomeni Z. 2011. The geothermal characteristics of the ground and the potential of using ground coupled heat pumps in Cyprus. Energy 36:5027-36.

Friso D. 2014. Energy saving with total energy system for cold storage in Italy: mathematical modeling and simulation, exergetic and economic analysis. App Math Sci 8:6529-46.

Fujii H., Ohyama K. 2009. Application of ground source heat pumps for air conditioning of greenhouses. IEA Heat Pump Centre Newslett. 27:39-42.

Ganguly A., Misra D., Ghosh S. 2010. Modeling and analysis of solar photovoltaic-electrolyzer-fuel cell hybrid power system integrated with a floriculture greenhouse. Energ. Build. 42:2036-43.

Giacomelli G.A., Sase S., Cramer R., Hoogeboom J., MacKenzie A., Parbst K., Scarascia-Mugnozza G., Selina P., Sharp D.A., Voogt J.O., Van Weel P.A., Mears D. 2012. Greenhouse production systems for people. Acta Hort. 927:23-38. 
Gu Y., O'Neal D.L., 1998. Development of an equivalent diameter expression for vertical U-tubes used in ground-coupled heat pumps. ASHRAE Trans. 104:347-55.

Kondili E., Kaldellis J.K. 2006. Optimal design of geothermal-solar greenhouses for the minimisation of fossil fuel consumption. Appl. Therm. Eng. 26:905-15.

Llopis G., Rodrigo V. 2008. Geothermal energy guide. FENER, Madrid, Spain. [Article in Spanish]

Lund J.W., Freeston D.H., Boyd, T.L. 2005. Direct application of geothermal energy: 2005 worldwide review. Geothermics 34:691-727.

0’Sullivan M., Yeh A., Mannington W. 2010. Renewability of geothermal resources. Geothermics 39:314-20.

Ozgener 0.2010. Use of solar assisted geothermal heat pump and small wind turbine systems for heating agricultural and residential buildings. Energy 35:262-8.

Ozgener 0., Hepbasli A. 2005. Performance analysis of a solar groundsource heat pump system for greenhouse heating: an experimental study. Build Environ. 40:1040-50.

Pascuzzi S., Anifantis A.S., Blanco I., Scarascia-Mugnozza G. 2016a. Electrolyzer performance analysis of an integrated hydrogen power system for greenhouse heating: a case study. Sustainability 8:629.

Pascuzzi S., Anifantis A.S., Blanco I., Scarascia-Mugnozza G. 2016b. Hazards assessment and technical actions due to the production of pressured hydrogen within a pilot photovoltaic-electrolyzer-fuel cell power system for agricultural equipment. J. Agr. Eng. 507:88-93.

Remund C.P. 1999. Borehole thermal resistance: laboratory and field studies. ASHRAE Trans. 105:439-45.

Rybach L. 2010. $\mathrm{CO}_{2}$ emission mitigation by geothermal development $\mathrm{e}$ especially with geothermal heat pumps. Proc.World Geothermal Congress, Apr 25-30, Bali, Indonesia.

Russo G., Anifantis A.S., Verdiani G., Scarascia Mugnozza G. 2014 Environmental analysis of geothermal heat pump and LPG greenhouse heating systems. Biosyst. Eng. 127:11-23.
Saner D., Juraske R., Kubert M., Blum P., Hellweg S., Bayer P. 2010. Is it only $\mathrm{CO}_{2}$ that matters? A life cycle perspective on shallow geothermal systems. Renew. Sust. Energy Rev. 14:1798-813.

Sethi V.P., Sharma S.K. 2008. Survey and evaluation of heating technologies for worldwide agricultural greenhouse applications. Sol. Energy 82:832-59.

Sharqawya M.H., Mokheimerb E.M., Badr H.M. 2009. Effective pipe-toborehole thermal resistance for vertical ground heat exchangers. Geothermics 38:271-7.

Shonder J.A., Beck J.V., 1999. Field test of a newmethod for determining soil formation thermal conductivity and borehole resistance. ASHRAE Trans. 106:843-50.

SIA (Swiss Society of Engineer and Architects). 2010. SIA 384/6:2010. Geothermal probes. Available from: http://www.webnorm.ch/ 6f988cd3-3425-451f-ad68-97684d1349e5/D/DownloadAnhang [ In Italian].

Tinti F. 2009. Geotermia per la climatizzazione. Flaccovio Editore, Palermo, Italy.

VDI (Verein Deutscher Ingenieure). 2009. Richtlinien VDI 4640 Blatt 2: Thermische Nutzung des Untergrundes - Erdgekoppelte Wärmepumpenanlagen. Available from: https:/www.vdi.de/technik/fachthemen/energie-und-umwelt/fachbereiche/energiewandlung-und-anwendung/richtlinien/vdi-4640/richtlinienreihe-vdi4640-thermische-nutzung-des-untergrunds/

VDI (Verein Deutscher Ingenieure). 2004. Richtlinien VDI 4640 Blatt 4: Thermische Nutzung des Untergrundes - Direkte Nutzungen. Available from: https://www.vdi.de/technik/fachthemen/energieund-umwelt/fachbereiche/energiewandlung-und-anwendung/ richtlinien/vdi-4640/richtlinienreihe-vdi-4640-thermischenutzung-des-untergrunds/

Vox G., Schettini E., Lisi Cerone A., Anifantis A. 2008. Solar thermal collectors for greenhouse heating. Acta Hort. 801:787-94. 